\title{
IRONI PEMILIHAN UMUM DI INDONESIA DALAM PUISI "KETIKA INDONESIA DIHORMATI DUNIA" KARYA TAUFIK ISMAIL
}

\author{
The Irony of Indonesian Elections in Poetry "Ketika Indonesia Dihormati Dunia" \\ by Taufik Ismail
}

\author{
Basori \\ Balai Bahasa Kalimantan Tengah \\ Jalan Tingang Km 3,5, Palangka Raya \\ tjakbasori@gmail.com
}

(Naskah Diterima Tanggal 26 Februari 2020_Direvisi Tanggal 25 Maret 2020_Disetujui Tanggal 1 April 2020)

\begin{abstract}
Abstrak
Pemilihan umum merupakan peristiwa rutin dalam sebuah negara yang menganut sistem demokrasi. Taufik Ismail yang merupakan salah satu penyair produktif di Indonesia juga mencatat peristiwa pemilihan umum ini. Penelitian ini mengambil salah satu puisi Taufik Ismail yang bertema pemilihan umum, yakni Ketika Indonesia Dihormati Dunia (KIDD). Puisi KIDD dikaji unsur-unsur ironinya dalam membentuk makna. Ciri dan jenis ironi yang ada di dalamnya serta bagaimana ironi-ironi tersebut membangun makna yang diinginkan oleh penyair. Ciri tuturan ironi yang ditemukan dalam KIDD adalah kesenjangan semantis dan pemakaian gaya hiperbol. Kesenjangan semantis ditandai oleh kontradiksi leksikal, penjajaran kata yang mengandung komponen makna yang bertentangan, serta pemakaian atau penyisipan kata dengan laras yang kontras. Pemakaian hiperbol merupakan unsur yang paling kuat terlihat dalam KIDD. Tampaknya ini merupakan gaya yang khas Taufik Ismail. Ciri tuturan yang hiperbol itu ditandai oleh adanya pelanggaran terhadap maksim kuantitas dan maksim kualitas. Kajian atas jenis ironi menunjukkan bahwa puisi KIDD mengandung jenis ironi verbal sebagai bagian struktur pengucapan ironi. Jenis yang juga ditemukan dalam kajian ini adalah jenis ironi situasi. Ciri dan jenis ironi tersebut digunakan untuk membangun kritik, sindiran, dan cemooh terhadap bangsa Indonesia. Kritik, sindiran, dan cemooh tersebut disusun dalam sebuah pembandingan atau kontras antara masa lalu dan masa kini.
\end{abstract}

Kata Kunci: ironi, puisi, Taufik Ismail, KIDD

\begin{abstract}
The events that occur in the environment are inseparable from the observations and works of writers. Likewise about general elections. Elections are routine events in a country that adopts a democratic system. Taufik Ismail, who is one of the most prolific poets in Indonesia, also noted this election event. This research takes one of Taufik Ismail's poems with the theme of the general election, namely When Indonesia is Honored by the World (KIDD). KIDD's poetry is examined by its ironic elements in shaping meaning. Characteristics and types of irony that is in it and how the irony builds the meaning desired by the poet. Characteristics of irony utterances found in KIDD are semantic disparities and the use of hyperbolic force. Semantic disparities are characterized by lexical contradictions, the juxtaposition of words containing conflicting components of meaning, and the use or insertion of words with contrasting tunings. The use of hyperbole is the most powerful element seen in KIDD. This seems to be a style that is typical of Taufik Ismail. Hyperbolic speech is characterized by a violation of the quantity and quality maxim. The study of the type of irony shows that the KIDD poem contains a type of verbal irony as part of the structure of the pronunciation of irony. The type also found in this study is the type of situational irony. These characteristics and types of irony are used to build criticism, satire, and ridicule towards the Indonesian people. Such criticism, satire, and derision are arranged in a comparison or contrast between the past and the present.
\end{abstract}

Keyword: irony, poetry, Taufik Ismail, KIDD 


\section{PENDAHULUAN}

Lima tahun sekali Indonesia mengadakan pemilihan umum. Pemilihan umum yang bertujuan untuk memilih para pemimpin di negeri ini. Pemilu adalah rutinitas abadi sebagai sebuah negara. Lewat proses itu, rakyat melaksanakan haknya sebagai warga negara. Hak untuk memilih wakil-wakilnya, pemimpinnya. Sejak masa reformasi (1998), terhitung sudah lima kali negeri ini mengadakan pemilu. Selalu saja terdapat masalah dalam setiap pelaksanaannya. Ketidakrelaan untuk kalah; ketinggihatian pemenang; silang sengkarut dalam perhitungan suara; ketegangan di antara masyarakat adalah masalah-masalah yang kerap muncul dalam setiap pemilihan umum.

Sastra hidup di masyarakat. Ia tidak akan pernah lepas dari kehidupan masyarakat. Pada titik tertentu sastra adalah potret kehidupan masyarakat. Demikian pula yang terjadi dengan sejarah pemilu di Indonesia. Pengarang-pengarang Indonesia memotretnya melalui karya-karyanya. Taufik Ismail, Wiji Thukul, W.S. Rendra, Remi Silado, dan banyak lagi pengarang yang mencatat pengalamannya tentang pemilu di Indonesia. Mereka mengekspresikannya dalam berbagai bentuk. Puisi, cerpen, bahkan komik.

Sastra adalah bahasa. Tidak ada sastra tanpa bahasa. Dalam berkarya, pengarang mengeksploitasi kemampuan berbahasanya. Hal itu memungkinkan munculnya bentuk bahasa yang berbeda dengan bahasa seharihari. Ini yang disebut sebagai bahasa sistem kedua. Akan tetapi, bahasa sastra tetaplah sebuah sistem komunikasi. Pengarang mengomunikasikan ide dan gagasannya lewat sebuah karya. Melalui karya itu, pembaca memahami ide dan gagasan pengarang.

Sebagai sistem komunikasi, bahasa sistem pertama hanya melibatkan dua subjek, penutur dan mitra tutur. Sementara itu, dalam bahasa sistem kedua, komunikasi antara penutur dan mitra tutur dimediasi oleh para narator, jenis-jenis pelaku, peristiwa implisit, jenis-jenis pengarang, serta jenisjenis pembaca dan pendengar lainnya. Hal ini yang membuat komunikasi dalam sastra menjadi rumit. Komunikasi sastra melibatkan interaksi sosial, aktivitas bahasa, sekaligus mekanisme teknologi. Dalam sastra bahasa dimodifikasi secara artifisial oleh pengarang. Dengan demikian, sastra adalah sebuah tuturan. Jika sastra adalah sebuah tuturan, hal itu mengindikasikan adanya penutur dan mitra tutur. Penutur tentu saja adalah pengarang yang menyusun pesan-pesan dalam karya yang dikomunikasikannya kepada pembaca sebagai mitra tuturnya. Kleden (2004: 277) menyatakan bahwa seorang penyair menulis puisi karena dua alasan, yaitu, adanya dorongan hati untuk mengejewantahkan kemampuannya dalam mencipta dan merealisasikan bakat serta untuk menyampaikan sesuatu yang lain.

Bagi Taufik Ismail puisi adalah sebuah nyanyian, dan ia berniat bernyanyi hingga akhir hayat. Baginya nyanyian yang indah dapat menyenangkan pendengarnya. Puisi adalah cinta yang luas maknanya. Puisi adalah bagian keimanan. Puisi adalah sarana mengingatkan diri agar tak lekang mengenang hari akhir yang abadi. Puisi juga merupakan media untuk meratap, menangis, bila kesedihan tak tertahankan. Puisi adalah cara untuk mengecam adanya kezaliman, penindasan, dan kesewenangwenangan yang terasa buruk dan busuk, sekaligus sebagai saksi berbagai peristiwa dalam sejarah. Puisi-puisi Taufik senantiasa hadir dan mengalir di tengah masyarakat pembaca sastra. Bahkan secara tersurat atau tersirat, dalam proses penulisan maupun proses sosialisasi karyanya, Taufik tak pernah lelah menegur dan mengkritisi perjalanan sejarah bangsanya (Sayuti 2005: 8-9).

Puisi-puisi Taufik Ismail kental dengan kritik sosial. Hal itu menunjukkan bahwa ia adalah penyair yang peka terhadap realitas. Realitas yang terjadi di lingkungannya. Taufik Ismail adalah 
seorang penyair besar. Ia menulis karena adanya dorongan nurani, menulis untuk menunjukkan kepeduliannya terhadap sesama. Ia tidak berkarya untuk dirinya sendiri, tetapi karena tuntutan nurani untuk berbuat sesuatu bagi lingkungannya. Ada dua puisi Taufik Ismail yang membahas tentang pemilu. Puisi dengan judul "Berbeda Pendapat" yang dimuat dalam kumpulan puisi Malu (Aku) Jadi Orang Indonesia dan "Ketika Indonesia Dihormati Dunia" yang dibacakan pertama kalinya dalam deklarasi pemilu damai menjelang pelaksanaan Pemilu 2004.

Pembahasan atau penelitian puisipuisi Taufik Ismail sudah banyak dilakukan. Hal ini tidak hanya karena Taufik Ismail seorang penyair besar, tetapi karya-karya Taufik yang monumental selalu menarik perhatian banyak peneliti. Pada bagian ini dipaparkan penelitian-penelitian yang menggunakan puisi-puisi Taufik Ismail sebagai objek kajian dan penelitianpenelitian yang menggunakan ironi sebagai unit analisisnya. Tercatat Santosa (2002), Sudardi (2005), Sayuti (2005), Iswatiningsih (2005), Hamzah (2010), Kusumawati (2013), Shirazy (2014), Martalena (2016), Susilo et al. (2018), Aditya et al. (2018), Septia et al. (2019), dan Febrina (2019) pernah melakukan penelitian terhadap puisipuisi Taufik Ismail.

Beberapa peneliti yang membahas tentang ironi antara lain (Choon-Soo, 1990), Husen (1990), Zaidan (1992), Giora \& Fein (1999), Giora (2001), Penny (2011), dan Salikha (2017).

Santosa (2002) mengulas beberapa puisi Taufik Ismail dalam Malu (Aku) Jadi Orang Indonesia (MAJOI). Ia menyatakan bahwa puisi-puisi dalam MAJOI mempunyai ciri berkabar. Dalam penelitiannya, Santosa tidak hanya menelaah beberapa puisi yang terdapat pada buku MAJOI, tetapi juga membandingkannya dengan puisi-puisi yang diciptakan Taufik Ismail pada kurun waktu sebelumnya. Menurut Santosa, beberapa puisi Taufik dalam MAJOI mempunyai hubungan intertekstual dengan puisi yang ditulis Taufik sebelumnya. Misalnya, puisi "Karangan Bunga" dan "Salemba" (Tirani dan Benteng) dengan "12 Mei 1998" (MAJOI).

Selain pernah ditelaah Santosa, puisipuisi Taufik Ismail dalam MAJOI juga pernah dibahas oleh Sudardi. Sudardi (2005) membahas puisi-puisi Taufik dalam MAJOI dengan sudut pandang ilmu sosial.

Sayuti (2005) tidak hanya membahas puisi-puisi Taufik dalam MAJOI, tetapi membahas pula puisi-puisi yang terdapat dalam kumpulan Tirani dan Benteng. Sayuti (2005: 53-95) menyatakan bahwa puisipuisi Taufik banyak mengandung refleksi moral dan kehidupan sosial. Puisi-puisi dalam MAJOI bukan sekadar reproduksi realitas, melainkan sesuatu yang berpotensi mempertajam dan membuat lebih intens penghayatan pada realitas. Selain mengulas MAJOI sebagai karya yang mengandung refleksi moral dan kehidupan sosial, Sayuti (2005) juga mengemukakan tentang gaya pengucapan Taufik Ismail dalam mengekspresikan gagasannya pada puisi. Menurutnya, hampir sebagian besar karya Taufik dalam MAJOI menggunakan gaya paradoks, gaya empati, dan gaya ironi. Akan tetapi, ia tidak merinci lebih lanjut gaya paradoks, gaya empati, dan gaya ironi yang digunakan oleh Taufik Ismail.

Iswatiningsih (2005) mengulas puisipuisi Taufik Ismail dalam MAJOI. berdasarkan penelitiannya, ia menyimpulkan bahwa makna yang terkandung dalam puisi-puisi dalam MAJOI meliputi ideologi, keserakahan, pahlawan reformasi, lahirnya reformasi, taubat, kebobrokan sebuah bangsa, dan rasa peduli kepada sesama.

Kusumawati (2010) juga meneliti MAJOI. Penelitian ini menyimpulkan bahwa puisi-puisi dalam MAJOI mengandung tema-tema yang terkait dengan pendidikan karakter bangsa dan tema pokok/inti dari puisi tersebut.

Penelitian Zaidan (1992) berkaitan dengan ironi dalam puisi Gunawan 
Mohamad. Penelitian ini menghasilkan ciri tuturan ironi yang dominan dalam sajaksajak Goenawan Mohamad. Ciri tersebut adalah kesenjangan semantis yang disebabkan oleh kontradiksi leksikal dan ciri tuturan ironis yang berupa kontradiksi ujaran penuturnya. Ciri tuturan yang melebihlebihkan dan kontradiksi tuturan dengan kenyataan sebagai konteks sosial budaya tidak banyak ditemukan. Kajian atas jenis ironi menunjukkan bahwa beberapa sajak Goenawan Mohamad mengandung jenis ironi verbal sebagai bagian struktur pengucapan ironi. Jenis yang juga ditemukan dalam kajian ini adalah jenis ironi struktural. Jenis ini terdapat dalam sajak Goenawan Mohamad yang panjang. Ironi tragis merupakan jenis ketiga yang ditemukan dalam kajian ini. Sebagai bagian ironi dramatik, ironi tragis dalam sajak-sajak Goenawan Mohamad berhasil menciptakan situasi ironis. Makna ironi yang dapat dirumuskan dari sajak-sajak yang dipilih pada umumnya bersandar pada penampilan kata atau ungkapan yang paradoks. Dalam kaitan itu, paradoks selalu menjadi dasar mekanisme pengujaran ironi yang menunjang makna ironi itu sendiri.

Puisi KIDD karya Taufik Ismail akan dibedah menggunakan teori ironi. Grice (1976) mengulas ironi dengan sangat singkat. Ia hanya menyebut bahwa ironi adalah salah satu contoh dari pelanggaran bidal kualitas. Menurut Grice, ironi sangat terkait dengan ekspresi suatu perasaan atau sikap. Seorang tidak bisa mengucapkan sesuatu secara ironis kecuali jika yang diucapkannya dimaksudkan untuk merefleksikan sesuatu penilaian yang bersifat memusuhi (hostile) atau menghina (derogatory), atau untuk merefleksikan perasaan marah atau jijik. Sayangnya, Grice tidak mengelaborasi ironi secara lebih mendalam.

Searle (1979) pun hanya sedikit menyinggung soal ironi. Menurutnya, setiap kebudayaan baik secara linguistis maupun ekstralinguistis terdapat ironi. Dalam bahasa Inggis terdapat intonasi berkarakteristik tertentu yang menyertai ironi. Akan tetapi, ironi tidak membutuhkan konvensi atau yang lainnya. Searle berpendapat bahwa prinsip-prinsip percakapan dan aturan-aturan umum untuk membuat tindak tutur cukup untuk tersedianya prinsip-prinsip dasar ironi.

Berbeda dengan Grice dan Searle, (Leech, 1983) memandang ironi dapat dijadikan suatu prinsip tersendiri. Ia pun mengajukan prinsip baru, yakni Prinsip Ironi (Irony Principle). Ia merumuskan prinsip ironi (PI) sebagai sebuah prinsip urutan kedua yang memanfaatkan, bahkan dibangun, di atas prinsip kesantunan (PS). PI mengambil tempat di sisi PK dan PS. Prinsip ini memungkinkan seseorang untuk bertindak tidak santun melalui sikap atau tuturan yang seolah-olah santun. Hal itu bisa dilakukan dengan memberi kesan melanggar PK tetapi sebetulnya menaatinya. PS dalam hal ini mendorong terwujudnya hubungan yang ramah dan menghindari konflik dalam hubunganhubungan sosial, sedangkan PI, dengan memungkinkan kita untuk bertindak tidak santun, memupuk penggunaan bahasa yang antisosial.

Daya ironi sebuah pernyataan sering ditandai oleh pernyataan yang berlebihan atau pernyataan yang mengecilkan arti, sehingga menjadi lebih sulit bagi mitra tutur untuk menginterpretasi pernyataan tersebut dengan segera. Prinsip ironi ini digunakan untuk menjaga pencapaian sebuah tujuan sosial, artinya bahwa seorang penutur demi tercapainya tujuan sosial (misalnya menghormat), maka dipergunakan prinsip ironi. Prinsip ironi berbeda dengan prinsip kerja sama. Leech (1983: 224) menyatakan prinsip ini merupakan parasit prinsip kerja sama dan prinsip kesopanan. Maksudnya prinsip ini dys fungsional; yaitu prinsip kesantunan mendorong terjadinya hubungan yang ramah dan menghindari konflik. Prinsip ironi memungkinkan untuk bertindak tidak sopan, dan memupuk penggunaan bahasa yang asosial.

Meskipun prinsip ironi ini terlihat $d y s$ fungsional, karena menyediakan cara untuk menyinggung perasaan, namun prinsip ini 
juga mempunyai fungsi positif. Fungsi positif tersebut tampak pada sikap-sikap agresif yang tersalurkan dalam bentukbentuk verbal yang tidak berbahaya. Prinsip ini menggunakan bentuk-bentuk bela diri yang memadukan seni menyerang dengan sebuah keluguan (Leech 1983: 227).

Ironi merupakan cara pengungkapan yang bersifat ganda, pandangan yang sebenarnya terkandung hanya dikemukakan secara samar-samar. Ironi juga disebut sebagai kritik terselubung yang sering menimbulkan efek jenaka pada penerima yang bijak asalkan dilakukan berdasarkan pemilihan yang tepat tetapi luwes dan lincah. Karena sifat maknanya yang terselubung itu, untuk memahami ironi diperlukan tingkat penguasaan bahasa yang tinggi. Dalam kaitan itu, Husen (1990: 6) menegaskan bahwa pemaharnan ironi itu tidak hanya memerlukan penguasaan bahasa yang tertinggi, tetapi juga pengetahuan sosial budaya yang mencukupi untuk memahami unsur-unsur aktualitas karya ketika diciptakan. Aktualitas karya ketika karya itu diciptakan adalah konteks sosial budayanya. Oleh karena itu, pengetahuan tentang konteks karya itu, termasuk konteks pengucapan ironi, merupakan hal yang penting. Tidak berlebihan kalau Fowler (1991: 128) menegaskan bahwa kekuatan ironi tergantung pada keberhasilan pengarang mengeksploitasi jarak antara kata-kata atau kejadian dan konteksnya. Dengan cara itu, makna ironi menjadi ambigu, dan dengan sendirinya menuntut wawasan yang lebih luas untuk memahaminya.

Choon-soo (1990) memandang ironi sebagai cara pengucapan puitis dan pada sisi lainnya konsepsi puitis itu sendiri. Pengertian ironi yang kedua menjadikan puisi sebagai karya yang padat kata dan sarat makna dengan ketaklangsungan ungkapan. Atas dasar pengertian ini, jelas bahwa setiap puisi selalu mengandung ironi yang merupakan prinsip struktur puisi itu sendiri. Dalam pengertian seperti ini, ironi diberi arti yang lebih luas sehingga dapatlah dikatakan bahwa semua pengucapan puisi itu ironis.

Berdasarkan beberapa sumber, Husen (1990: 71-80) menegaskan bahwa dalam tuturan ironis terdapat perbedaan antara apa yang dinyatakan secara harfiah dan maksud pengarang sebenarnya yang kadang-kadang ditemukan dalam makna yang berlawanan. Oleh karena itu, tuturan ironis selalu ambigu. Selain itu, dalam tuturan ironis selalu terkandung sikap menilai dan kadangkadang sampai pada tataran mencemooh. Tentang ciri-ciri ironi, Husen (1990: 88-89) mengemukakan beberapa hal yang mencakupi kesenjangan semantis yang disebabkan oleh kontradiksi leksikal, kontras dalam penggunaan laras, gaya penulisan yang berlebih-lebihan yang diungkapkan dengan perbandingan superlatif atau dengan hiperbol, dan kontras antara yang tertulis dan konteks ekstralinguistik.

Ironi dapat dibedakan ke dalam dua kelompok besar, yakni ironi verbal dan ironi dramatik. Ironi verbal adalah ironi yang dinyatakan dalam kata-kata. Fowler (1991: 129) menyatakan bahwa ironi verbal biasanya beroperasi dengan mengeksploitasi penyimpangan kaidah sintaksis atau semantik dan kemampuan untuk mengenalnya tergantung pada tingkat apresiasi kebahasaan yang khusus, atau pada konteks sosial atau moral yang lebih umum. Dalam tuturan, ironi verbal seringkali ditunjang oleh nada bicara dan mimik muka. Di dalam puisi, ironi verbal lebih sulit dikenali tetapi paling banyak dipakai.

Ironi dramatik disebut juga ironi situasi. Dalam teori sastra, ironi dramatik sering dikaitkan dengan nasib tragis yang dialami tokoh Oedipus dalam tragedi Yunani. Berbeda dengan ironi verbal, ironi dramatik tidak diungkapkan dalam kata-kata tetapi dalam perbuatan atau lakuan tokoh. Ironi dramatik dapat juga dipandang sebagai kesan yang diperoleh pembaca menyangkut kejadian yang dialami tokoh rekaan yang memperlihatkan adanya kesenjangan (bahkan pembalikan) antara yang 
diharapkan dan kenyataan yang dialami. Ironi dramatik baru dapat dipahami dalam konteks keseluruhan karya itu. Tidak jarang pada bagian teks ditemukan ciri-ciri ironi verbal yang menunjangnya.

Ada pula yang disebut sebagai ironi struktural (Abrams, 1981). Ironi jenis ini berbeda dengan ironi verbal dan ironi dramatik. Ironi struktural ini menyisipkan satu bagian struktur yang menunjang kemenduaan arti. Biasanya bagian struktur itu adalah tokoh naif atau dapat juga pencerita. Kesederhanaan dan kedunguan tokoh naif atau pencerita naif itu meneguhkan satu interpretasi atas peristiwa yang berbeda dari yang ditanggapi pembacanya. Ia juga memasukkan sarkasme dan kata-kata caci maki sebagai ironi yang dihubungkan dengan pemakaian bahasa.

Dalam penelitian ini, konsep Grice (1976) dan Husen (1990) mengenai ciri-ciri ironi diterapkan bersama dengan jenis ironi dari Fowler (1991). Konsep ironi struktural dari Abrams (1981) tidak bisa diterapkan dalam penelitian ini karena data yang ada tidak menunjukkan adanya ironi jenis struktural sebagaimana yang dikemukakannya.

\section{METODE}

Penelitian ini merupakan penelitian lintas disiplin yang berusaha untuk mengupas bahasa secara interpretatif untuk menemukan pemahaman tentang kebudayaan. Oleh karena itu, pendekatan yang digunakan bersifat eklektik dengan tetap mempertahankan kekhasannya dalam pemilihan data kebahasaan sebagai objek studi (yakni parole). Ancangan penelitian yang digunakan bersifat ideografis dan kecenderungan penerapan metodologi kualitatif pendekatan fenomenologis.

Berdasarkan pada konsep tersebut, karya yang dikaji dianalisis secara tekstual tanpa mengaitkan dengan hal-hal di luar teks. Pikiran-pikiran penyair yang melatari kelahiran puisi dijadikan sebagai kerangka acuan penafsiran sebagai wujud teori yang khas. Dalam analisis, teks puisi disajikan secara utuh. Selanjutnya diamati ciri tuturan ironinya serta makna yang tersirat di dalamnya.

Langkah analisis dimulai dengan klasifikasi dan kodifikasi ironi dalam puisi KIDD. Data yang sudah didapatkan diklasifikasikan berdasarkan ciri dan jenis ironinya. Berdasarkan cirinya, data diklasifikasikan ke dalam ironi yang berciri kesenjangan semantis, hiperbol, dan kontras tuturan dan kenyataan. Berdasarkan jenisnya, data diklasifikasikan ke dalam ironi verbal dan ironi situasi. Langkah berikutnya adalah mengungkapkan bagaimana dan mengapa suatu ironi tertentu digunakan dalam puisi, baik secara kontekstual maupun asosiatif, dalam hubungannya dengan tema yang disampaikan.

\section{PEMBAHASAN}

\section{Puisi Ketika Indonesia Dihormati Dunia}

Dengan rasa rindu kukenang pemilihan umum setengah abad yang lewat

Dengan rasa kangen pemilihan umum pertama itu kucatat

Peristiwa itu berlangsung tepatnya di tahun lima puluh lima

Ketika itu sebagai bangsa kita baru sepuluh tahun merdeka

5 Itulah pemilihan umum yang paling indah dalam sejarah bangsa

Pemilihan umum pertama, yang sangat bersih dalam sejarah kita

Waktu itu tak dikenal singkatan jurdil, istilah jujur dan adil 
Jujur dan adil tak diucapkan, jujur dan adil cuma dilaksanakan

Waktu itu tak dikenal istilah pesta demokrasi

10 Pesta demokrasi tak dilisankan, pesta demokrasi cuma dilangsungkan

Pesta yang bermakna kegembiraan bersama

Demokrasi yang berarti menghargai pendapat berbeda

Pada waktu itu tak ada huru-hara yang menegangkan

Pada waktu itu tidak ada setetes pun darah ditumpahkan

15 Pada waktu itu tidak ada satu nyawa melayang

Pada waktu itu tidak sebuah mobil pun digulingkan lalu dibakar

Pada waktu itu tidak sebuah pun bangunan disulut api berkobar

Pada waktu itu tidak ada suap-menyuap, tak terdengar sogok-sogokan

Pada waktu itu dalam penghitungan suara, tak ada kecurangan

20 Itulah masa, ketika Indonesia dihormati dunia

Sebagai pribadi, wajah kita simpatik berhias senyuman

Sebagai bangsa, kita dikenal santun dan sopan

Sebagai massa kita jauh dari kebringasan, jauh dari keganasan

Tapi enam belas tahun kemudian, dalam 7 pemilu berturutan

25 Untuk sejumlah kursi, 50 kali 50 sentimeter persegi dalam ukuran

Rakyat dihasut untuk berteriak, bendera partai mereka kibarkan

Rasa bersaing yang sehat berubah jadi rasa dendam dikobarkan

Kemudian diacungkan tinju, naiklah darah, lalu berkelahi dan berbunuhan

Anak bangsa tewas ratusan, mobil dan bangunan dibakar puluhan

30 Anak bangsa muda-muda usia, satu-satu ketemu di jalan, mereka sopan-sopan

Tapi bila mereka sudah puluhan apalagi ratusan di lapangan

Pawai keliling kota, berdiri di atap kendaraan, melanggar semua aturan

Di kepala terikat bandana, kaus oblong disablon, di tangan bendera berkibaran

Meneriak-neriakkan tanda seru dalam sepuluh kalimat semboyan dan slogan

35 Berubah mereka jadi beringas dan siap mengamuk, melakukan kekerasan

Batu berlayangan, api disulutkan, pentungan diayunkan

Dalam huru-hara yang malahan mungkin, pesanan

Antara rasa rindu dan malu puisi ini kutuliskan

Rindu pada pemilu yang bersih dan indah, pernah kurasakan

40 Malu pada diri sendiri, tak mampu merubah perilaku bangsaku.

\section{Ciri Tuturan Ironi dalam Puisi KIDD Kesenjangan Semantis}

Kesenjangan semantis merupakan ciri ujaran ironi yang ditemukan dalam puisi KIDD. Kesenjangan semantis yang menjadi kecenderungan utama gaya tuturan puisipuisi Taufik Ismail adalah yang disebabkan oleh kotradiksi leksikal. Kontradiksi leksikal ini ditunjukkan oleh penggunaan kata yang memiliki komponen makna yang berbeda. Kontradiksi leksikal berikut menunjukkan penempatan leksis yang memperlihatkan kontras penyifatan yang menampilkan situasi paradoks.

(1) Anak bangsa muda-muda usia, satu-satu ketemu di jalan, mereka sopan-sopan I.../ positif

Berubah mereka jadi beringas dan siap mengamuk, melakukan kekerasan negatif 
(2) Antara rasa rindu dan malu puisi ini kutuliskan

$$
\text { positif negatif }
$$

Data (1) dan (2) menunjukkan kesan paradoks yang ditimbulkan oleh penjajaran kata yang memunculkan suasana ironis. Sopan pada data (1) bermakna beradab dalam tingkah laku dan budi bahasa (KBBI 2001: 1084) dijajarkan dengan beringas, mengamuk yang memiliki makna berlawanan dengan sopan. Dalam Kamus Besar Bahasa Indonesia (KBBI) beringas bermakna liar (KBBI 2001: 140), mengamuk bermakna menyerang membabi buta (KBBI 2001: 41). Demikian pula dengan malu dan rindu pada data (2). Salah satu komponen makna adjektiva malu adalah negatif, sementara rindu memiliki komponen makna yang positif. Kesenjangan semantis juga dilakukan dengan cara penjajaran kata yang mengandung komponen makna yang bertentangan sehingga menimbulkan paradoks. Hal itu menimbulkan ketaksaan yang lebih menuntut pengetahuan konteks ekstralinguistik. Penjajaran leksis dengan sifat seperti itu tampak pada data berikut.

(3) Jujur dan adil tak diucapkan, jujur negatif

dan adil Cuma dilaksanakan positif

(4) Pesta demokrasi tak dilisankan, pesta negatif

demokrasi cuma dilangsungkan positif

Penjajaran kata yang menimbulkan kesenjangan semantis sebagaimana tampak pada data (3) dan (4) menunjukkan bahwa paradoks menjadi unsur utama ujaran ironi. Verba negatif tak diucapkan dan tak dilisankan yang dijajarkan dengan verba positif dilaksanakan dan dilangsungkan pada data (3) dan (4) menunjukkan kontras penyifatan terhadap nomina jujur dan adil serta pesta demokrasi yang disebut sebelumnya. Kontras penyifatan seperti ini menimbulkan efek ironi yang kuat.

\section{Hiperbol}

Sebagai ciri ujaran ironi, pemakaian hiperbol dapat ditemukan dalam puisi KIDD. Pemakaian hiperbol ini didasarkan pada pelanggaran terhadap prinsip-prinsip pragmatik, terutama maksim kuantitas dan maksim kualitas. Berikut ini adalah beberapa data pemakaian hiperbol dalam bentuk pelanggaran maksim kualitas.

(5) Untuk sejumlah kursi, 50 kali 50 sentimeter persegi dalam ukuran

(6) Anak bangsa tewas ratusan, mobil dan bangunan dibakar puluhan

(7) Meneriak-neriakkan tanda seru dalam sepuluh kalimat semboyan dan slogan

(1.34)

(8) Anak bangsa muda-muda usia, satu-satu ketemu di jalan, mereka sopan-sopan/Tapi bila mereka sudah puluhan apalagi ratusan di lapangan

$$
\text { (1.30 s.d. 1.31) }
$$

Data (5) sampai dengan (8) menggunakan numeralia sebagai alat untuk menyatakan jumlah. Dalam menyusun puisi, penyair seringkali menggunakan numeralia yang sulit untuk dibuktikan kebenarannya. Penyebutan puluhan, ratusan, sepuluh, lima puluh merupakan alat yang digunakan oleh penyair untuk menggugah imaji pembaca. Dengan menyebut numeralia tersebut pembaca dibawa dalam suasana sebagaimana yang diinginkan oleh penyair.

Data berikut menunjukkan adanya pelanggaran terhadap maksim kuantitas. Pelanggaran terhadap maksim kuantitas dilakukan oleh penyair semata-mata untuk memperkuat imaji pembaca.

(9) Pada waktu itu tak ada huru-hara yang menegangkan/Pada waktu itu tidak ada setetes pun darah ditumpahkan/Pada waktu itu tidak ada satu nyawa melayang/Pada waktu itu tidak sebuah 
mobil pun digulingkan lalu dibakar/Pada waktu itu tidak sebuah pun bangunan disulut api berkobar/Pada waktu itu tidak ada suap-menyuap, tak terdengar sogoksogokan/Pada waktu itu dalam penghitungan suara, tak ada kecurangan

$$
\text { (1.13 s.d. 1.19) }
$$

(10) Untuk sejumlah kursi, 50 kali 50 sentimeter persegi dalam ukuran/ Rakyat dihasut untuk berteriak, bendera partai mereka kibarkan/ Rasa bersaing yang sehat berubah jadi rasa dendam dikobarkan/ Kemudian diacungkan tinju, naiklah darah, lalu berkelahi dan berbunuhan/Anak bangsa tewas ratusan, mobil dan bangunan dibakar puluhan

$$
\text { (1.25 s.d. 1.29) }
$$

(11) Anak bangsa muda-muda usia, satu-satu ketemu di jalan, mereka sopan-sopan/Tapi bila mereka sudah puluhan apalagi ratusan di lapangan/Pawai keliling kota, berdiri di atap kendaraan, melanggar semua aturan/Di kepala terikat bandana, kaus oblong disablon, di tangan bendera berkibaran/ Meneriak-neriakkan tanda seru dalam sepuluh kalimat semboyan dan slogan/Berubah mereka jadi beringas dan siap mengamuk, melakukan kekerasan/Batu berlayangan, api disulutkan, pentungan diayunkan

$$
\text { (1.30 s.d. 1.36) }
$$

Data (9) menunjukkan pemakaian hiperbol yang berupa pelanggaran terhadap maksim kuantitas. Pelanggaran itu ditandai dengan adanya ungkapan yang berlebihan. Pengulangan bentuk pada waktu itu dalam setiap larik termasuk dalam kategori berlebihan. Demikian pula tuturan yang ada pada data (10) dan (11). Tuturan-tuturan tersebut merupakan bentuk hiperbol yang dibangun untuk memperkuat imaji pembaca (mitra tutur). Pemakaian hiperbol dalam puisi-puisi itu mempunyai dua fungsi, yakni untuk menciptakan metafora dan untuk menegaskan sindiran atau cemoohan, yang kadang-kadang sampai pada taraf sarkasme. Pemakaian hiperbol dapat mempertegas metafora dan menghidupkan imaji visual secara lebih kuat. Pemakaian hiperbol yang menimbulkan efek sindiran atau cemoohan lebih menonjolkan ciri ironinya.

\section{Jenis Ironi dalam Puisi KIDD}

\section{Ironi Verbal}

Ironi verbal adalah ironi kata-kata. Ironi jenis ini dapat langsung dikenali dengan hanya memperhatikan kata yang digunakan dalam puisi. Berikut ini adalah data yang menunjukkan penggunaan ironi verbal.

(12) Anak bangsa muda-muda usia, satu-satu ketemu di jalan, mereka sopansopan/.../Berubah mereka jadi beringas dan siap mengamuk, melakukan kekerasan

$$
\text { (1.30 s.d. 1.34) }
$$

(13) Antara rasa rindu dan malu puisi ini kutuliskan

(14) Jujur dan adil tak diucapkan, jujur dan adil cuma dilaksanakan

(15) Pesta demokrasi tak dilisankan, pesta demokrasi cuma dilangsungkan

Pada data (13) sampai dengan (16) terdapat penggunaan kata yang kontras untuk menegaskan ironi. Kontras makna yang timbul dari penjajaran kata sopan dan beringas, mengamuk, kekerasan pada data (12), adjektiva rindu dan malu pada data (13), verba negatif tak diucapkan dan tak dilisankan dengan verba positif cuma dilaksanakan dan cuma dilangsungkan pada data (14) dan (15) menimbulkan efek ironis bagi pembaca. Di samping itu, didapatka pula ironi verbal yang berupa penggunaan numeralia hiperbolik, seperti data berikut.

(16) Untuk sejumlah kursi, 50 kali 50 sentimeter persegi dalam ukuran

(17) Anak bangsa tewas ratusan, mobil dan bangunan dibakar puluhan

(18) Meneriak-neriakkan tanda seru dalam sepuluh kalimat semboyan dan slogan 
(19) Anak bangsa muda-muda usia, satu-satu ketemu di jalan, mereka sopan-sopan/Tapi bila mereka sudah puluhan apalagi ratusan di lapangan

$$
\text { (1.30 s.d. 1.31) }
$$

\section{Ironi Situasi}

Ironi situasi sebenarnya termasuk ironi dramatik dalam drama yang dalam puisi atau prosa biasa juga disebut ironi situasi. Ironi situasi baru dapat diketahui efek ironinya dalam keseluruhan makna puisi itu. Puisi KIDD mengungkapkan atau mengandung ironi situasi. Puisi ini menceritakan kegelisahan penutur melihat rentetan sejarah pemilu yang selalu meninggalkan persoalan, pemilu yang tidak pernah dibarengi dengan kejujuran, kedamaian. Penutur merasa malu dengan hal itu dan ia merindukan pemilu setengah abad yang lewat. Pemilu pertama dan satu-satunya yang berlangsung dengan damai, jujur, dan dipercaya oleh rakyat bahkan membangggakan bangsa di depan masyarakat dunia.

(20) Itulah pemilihan umum yang paling indah dalam sejarah bangsa

Pemilihan umum pertama, yang sangat bersih dalam sejarah kita

Waktu itu tak dikenal singkatan jurdil, istilah jujur dan adil

Jujur dan adil tak diucapkan, jujur dan adil cuma dilaksanakan

Waktu itu tak dikenal istilah pesta demokrasi

Pesta demokrasi tak dilisankan, pesta demokrasi cuma dilangsungkan

Pesta yang bermakna kegembiraan bersama

Demokrasi yang berarti menghargai pendapat berbeda

Pada waktu itu tak ada huru-hara yang menegangkan

Pada waktu itu tidak ada setetes pun darah ditumpahkan

Pada waktu itu tidak ada satu nyawa melayang

Pada waktu itu tidak sebuah mobil pun digulingkan lalu dibakar
Pada waktu itu tidak sebuah pun bangunan disulut api berkobar

Pada waktu itu tidak ada suap-menyuap, tak terdengar sogok-sogokan

Pada waktu itu dalam penghitungan suara, tak ada kecurangan

Itulah masa, ketika Indonesia dihormati dunia

Sebagai pribadi, wajah kita simpatik berhias senyuman

Sebagai bangsa, kita dikenal santun dan sopan

Sebagai massa kita jauh dari kebringasan, jauh dari keganasan

$$
\text { (1.5 s.d. } 1.23)
$$

(21) Tapi enam belas tahun kemudian, dalam 7 pemilu berturutan

Untuk sejumlah kursi, 50 kali 50 sentimeter persegi dalam ukuran

Rakyat dihasut untuk berteriak, bendera partai mereka kibarkan

Rasa bersaing yang sehat berubah jadi rasa dendam dikobarkan

Kemudian diacungkan tinju, naiklah darah, lalu berkelahi dan berbunuhan

Anak bangsa tewas ratusan, mobil dan bangunan dibakar puluhan

Anak bangsa muda-muda usia, satu-satu ketemu di jalan, mereka sopan-sopan

Tapi bila mereka sudah puluhan apalagi ratusan di lapangan

Pawai keliling kota, berdiri di atap kendaraan, melanggar semua aturan

Di kepala terikat bandana, kaus oblong disablon, di tangan bendera berkibaran

Meneriak-neriakkan tanda seru dalam sepuluh kalimat semboyan dan slogan

Berubah mereka jadi beringas dan siap mengamuk, melakukan kekerasan

Batu berlayangan, api disulutkan, pentungan diayunkan

Dalam huru-hara yang malahan mungkin, pesanan

$$
\text { (1.24 s.d. 1.37) }
$$

Data (20) dan (21) menunjukkan ironi situasi yang ditandai oleh suasana kontras yang dibangun melalui dua bait tersebut, Konjungsi tapi yang mengawali larik 24 [data (21)] memperkuat kesan ironis. Implikasi makna yang didapatkan dari data 
(20) adalah Itulah masa, ketika Indonesia dihormati dunia/Sebagai pribadi, wajah kita simpatik berhias senyuman/Sebagai bangsa, kita dikenal santun dan sopan/Sebagai massa kita jauh dari kebringasan, jauh dari keganasan. Larik-larik tersebut merupakan implikasi dari keberhasilan pelaksanaan pemilu yang jujur, bersih, tanpa kecurangan. Namun, bait ketiga puisi KIDD [data (21)] menyatakan hal yang berlawanan dengan implikasi tersebut. Bait ini memajankan keadaan yang serba negatif. Situasi ironis yang ditunjukkan dalam dua bait yang berbeda dalam puisi ini menjadi kritik terhadap bangsa ini. Bangsa ini pernah melaksanakan pemilu yang baik pada tahun 1955. Bangsa ini juga pernah melaksanakan pemilu yang tidak baik dalam masa rezim Orde Baru (1971, 1977, 1982, 1987, 1992, dan 1997). Dengan begitu mestinya, bangsa ini bisa belajar untuk melaksanakan pemilu yang baik, yang jujur dan adil. Namun, yang terjadi justru menaljutkan pemilu yang buruk, yang tidak jujur dan tidak adil (1999, 2004, dan 2009). Bangsa ini ternyata tidak bisa belajar dari pengalamannya sendiri. Atas dasar hal tersebut di akhir puisi penutur menyatakan perasaannya dengan /Antara rasa rindu dan malu puisi ini kutuliskan/Rindu pada pemilu yang bersih dan indah, pernah kurasakan/Malu pada diri sendiri, tak mampu merubah perilaku bangsaku/l.

\section{Fungsi dan Makna Makna Ironi dalam Puisi KIDD}

Puisi ini dibaca Taufik Ismail di gedung KPU pada 9 Maret 2004 sebelum dilaksanakannya pemilihan umum. Judul "Ketika Indonesia Dihormati Dunia" merupakan indeks dari keseluruhan isi puisi. Puisi ini memiliki dua bagian isi yang saling berkaitan, membentuk satu kesatuan harapan dan kerinduan penyair. Harapan dan kerinduan pada terwujudnya Indonesia yang dihormati dunia. Bagian pertama puisi ini secara jelas merepresentasikan keadaan masa pemilihan umum tahun 1955 .
Hal itu dinyatakan dengan penggunaan register yang merujuk pada peristiwa tersebut. Register-register tersebut antara lain, pemilihan umum setengah abad yang lewat, pemilihan umum pertama, peristiwa itu berlangsung tepatnya di tahun lima puluh lima, dan baru sepuluh tahun merdeka. Bagian kedua puisi ini berisi kabar tentang peristiwa pemilihan umum yang berlangsung setelahnya. Penanda yang menunjukkan hal tersebut adalah registerregister yang merujuk pada hal tersebut. Register yang menunjukkan hal itu adalah enam belas tahun kemudian dan 7 pemilu berturutan. Bagian kedua ini merepresentasikan keadaan Indonesia pada masa sekarang. Hal itu ditandai oleh penggunan register enam belas tahun dan tujuh pemilu berurutan. Jika diurutkan tujuh pemilu tersebut berlangsung pada tahun 1971, 1977, 1982, 1987, 1992, 1997, dan 1999.

Puisi KIDD hanya terdiri atas satu kalimat. Hal ini ditandai dengan penanda huruf kapital pada awal teks dan tanda titik yang ada pada akhir teks. Huruf kapital yang terdapat pada setiap awal larik dapat dianggap sebagai tanda konvensi penulisan tradisi perpuisian Melayu dan tanda awal klausa.

Larik pertama, //Dengan rasa rindu kukenang pemilihan umum setengah abad yang lewat// merupakan satu klausa pernyataan lengkap yang mesti diikuti oleh rangkaian pemerian. Klausa pada larik pertama puisi ini bersusunan inversi. K-P-S. Subjek klausa terletak pada frasa pemilihan umum setengah abad yang lewat, predikat pada kata kukenang, dan keterangan yang diletakkan di depan dalam bentuk dengan rasa rindu. Struktur kalimat tersebut menunjukkan penonjolan atau penguatan terhadap frasa dengan rasa rindu. Frasa ini menjadi lebih penting daripada subjeknya. Hal ini memberi kesan betapa kuatnya rasa rindu penutur pada sesuatu yang kemudian dinyatakan pada subjeknya.

Larik kedua semakin menguatkan kesan tersebut dengan corak klausa yang 
hampir sama, pengedepanan keterangan. Dengan rasa kangen pemilihan umum pertama itu kucatat// memiliki kedudukan yang sama dengan larik pertama. Untuk menghindari kejenuhan, susunan klausanya diubah meski tetap mendahulukan keterangan. Klausa kedua ini berpola K-S-P. Pengubahan struktur klausa ini mengimplikasikan adanya penekanan terhadap predikat. Seperti diketahui, katakata yang terdapat pada akhir larik puisi memperoleh tekanan semantik yang lebih kuat. Ini merupakan gejala enjambemen; struktur puisi yang menciptakan saat istirahat yang secara sintaktik tidak terdapat dalam kalimat. Istirahat antara kata kucatat dan bait berikutnya peristiwa menggarisbawahi makna kucatat. Klausa ini sebenarnya memiliki kedudukan yang sama dengan klausa pertama. Penyair hanya mengubah kata yang digunakannya untuk menyatakan perasaan, yaitu kata kangen. Rindu dan kangen merupakan sinonim, dalam KBBI (2001: 501 \& 956) Rindu dan kangen dimaknai sebagai sangat ingin dan berharap benar terhadap sesuatu. Dalam konteks puisi ini berarti penutur sangat ingin dan berharap benar terhadap peristiwa pemilu yang bersih, yang jujur sebagaimana yang pernah ia rasakan pada tahun 1955 . Demikian pula frasa yang menduduki posisi subjek, penyair mengubahnya dengan bentuk yang berbeda meskipun acuannya tetap. Pemilihan umum setengah abad yang lewat disubstitusi dengan pemilihan umum pertama. Dua klausa yang memiliki kedudukan sama, menyatakan rasa yang sama dalam bait pembuka puisi ini kemudian diikuti oleh dua bait yang merupakan perian dari pernyataan tersebut.

Bait kedua (1.3 s.d. 1.23) merupakan perian lebih lanjut dari bait pertama. Hal ini ditandai dengan penggunaan deiksis penunjuk itu. Larik ketiga merupakan satu klausa bebas yang berdiri sendiri, //Peristiwa itu berlangsung tepatnya di tahun lima puluh limall. Deiksis penunjuk itu setelah kata peristiwa menunjukkan bahwa peristiwa yang dimaksud dalam klausa ini adalah pemilihan umum setengah abad yang lewat dan pemilihan umum pertama yang telah disebutkan pada bait pertama. Klausa ini memberi tambahan informasi bahwa pemilihan umum setengah abad yang lewat yang dimaksud pada larik pertama itu berlangsung pada tahun lima puluh lima. Larik keempat masih merupakan perian yang menunjukkan waktu terjadinya pemilihan umum, yaitu saat baru sepuluh tahun merdeka.

Data (22) memberi informasi bahwa pemilu tersebut berlangsung dengan cara yang indah, bersih, jujur, adil, pesta yang sesungguhnya, yang membawa kegembiraan bersama, dan saling menghargai.

(22) Itulah pemilihan umum yang paling indah dalam sejarah bangsa

Pemilihan umum pertama, yang sangat bersih dalam sejarah kita

Waktu itu tak dikenal singkatan jurdil, istilah jujur dan adil

Jujur dan adil tak diucapkan, jujur dan adil cuma dilaksanakan

Waktu itu tak dikenal istilah pesta demokrasi

Pesta demokrasi tak dilisankan, pesta demokrasi cuma dilangsungkan

Pesta yang bermakna kegembiraan bersama

Demokrasi yang berarti menghargai pendapat berbeda

(23) Pada waktu itu tak ada huru-hara yang menegangkan

Pada waktu itu tidak ada setetes pun darah ditumpahkan

Pada waktu itu tidak ada satu nyawa melayang

Pada waktu itu tidak sebuah mobil pun digulingkan lalu dibakar

Pada waktu itu tidak sebuah pun bangunan disulut api berkobar

Pada waktu itu tidak ada suap-menyuap, tak terdengar sogoksogokan

Pada waktu itu dalam penghitungan suara, tak ada kecurangan

(1.13 s.d. 1.19)

Data (22) yang menggambarkan kebersihan dan keindahan pemilu 1955 dengan 
menggunakan klausa-klausa positif dilanjutkan dengan larik-larik yang ada pada data (23) yang menggambarkan keindahan dan kebersihan itu dengan cara yang berbeda. Larik-larik ini menggunakan bentuk-bentuk negatif. Hal ini dilakukan untuk memperkuat kesan keindahan dan kebersihan peristiwa tersebut. Struktur bentuk positif yang dibarengi dengan bentuk negatif demikian lazim digunakan untuk menjelaskan dan memperkuat makna. Struktur klausa yang dipakai pun menunjukkan keseragaman, yakni K-P-S. Keterangan pada waktu itu yang mengawali seluruh larik pada bagian ini merujuk pada peristiwa pemilu tahun lima puluh lima. Penjajaran ini menguatkan kesan terhadap peristiwa tersebut. Predikat yang berbentuk negatif dengan penggunaan tidak mengimplikasikan bahwa peristiwa tersebut benar-benar indah dan bersih.

(24) Itulah masa, ketika Indonesia dihormati dunia

Sebagai pribadi, wajah kita simpatik berhias senyuman

Sebagai bangsa, kita dikenal santun dan sopan

Sebagai massa kita jauh dari kebringasan, jauh dari keganasan

Data (24) merupakan implikasi dari keindahan dan kebersihan pemilihan umum tersebut. Pada bagian ini penutur melibatkan mitra tuturnya (pembaca implicit) sebagai bagian dari puisi. Pelibatan tersebut ditunjukkan dengan penggunaan bentuk kita pada tiga larik terakhir bait.

Bentuk ironi dengan menjajarkan susunan klausa positif pada data (22) yang diikuti oleh susunan klausa negatif pada data (23) menguatkan kesan positif yang terjadi dalam peristiwa pemilu 1955. Bahwa pemilu tersebut sampai sekarang diyakini sebagai pemilu yang paling bersih, paling jujur yang pernah dialami oleh rakyat Indonesia. Peristiwa yang berimplikasi pada penghargaan dunia terhadap bangsa Indonesia sebagaimana yang dijelaskan pada larik berikutnya.
(25) Tapi enam belas tahun kemudian, dalam 7 pemilu berturutan

Untuk sejumlah kursi, 50 kali 50 sentimeter persegi dalam ukuran

Rakyat dihasut untuk berteriak, bendera partai mereka kibarkan

Rasa bersaing yang sehat berubah jadi rasa dendam dikobarkan

Kemudian diacungkan tinju, naiklah darah, lalu berkelahi dan berbunuhan

Anak bangsa tewas ratusan, mobil dan bangunan dibakar puluhan

Anak bangsa muda-muda usia, satu-satu ketemu di jalan, mereka sopan-sopan

Tapi bila mereka sudah puluhan apalagi ratusan di lapangan

Pawai keliling kota, berdiri di atap kendaraan, melanggar semua aturan

Di kepala terikat bandana, kaus oblong disablon, di tangan bendera berkibaran

Meneriak-neriakkan tanda seru dalam sepuluh kalimat semboyan dan slogan

Berubah mereka jadi beringas dan siap mengamuk, melakukan kekerasan

Batu berlayangan, api disulutkan, pentungan diayunkan

Dalam huru-hara yang malahan mungkin, pesanan

(1.24 s.d. 1.37)

Data (25) merupakan bait ketiga puisi KIDD. Larik-larik yang ada dalam data (25) merupakan gambaran peristiwa masa berikutnya. Bait ini dimulai dengan kata tapi yang menunjukkan bahwa peristiwa yang digambarkan pada bagian ini adalah paradoks, kontras dengan peristiwa yang sudah digambarkan pada data (22) dan (23). Dimulai dengan deiksis waktu //enam belas tahun kemudian, dalam 7 pemilu berurutan// penyair memberi tekanan pada masa, waktu. Enam belas tahun kemudian merujuk pada enam belas tahun setelah tahun lima puluh lima. Dalam 7 pemilu berurutan merujuk pada tujuh peristiwa pemilu setelahnya, yakni pemilu tahun 1971, 1977, 1982, 1987, 1992, 1997, dan 1999. Mitra tutur (pembaca) mesti memahami sejarah bahwa pemilu di negeri ini dilaksanakan setiap lima tahun sekali. Kekecualian terjadi pada tahun 1999, pada masa kejatuhan pemerintahan Suharto yang kemudian memaksa dilaksanakannya 
pemilihan umum lebih cepat dari biasanya. Hal ini mengimplikasikan bahwa catatan terhadap sesuatu itu akan selalu berkaitan dengan waktu, karena dalam waktulah sejarah itu berasal. Larik kedua bait ketiga merupakan keterangan tambahan yang memberi informasi sesuatu yang diperebutkan dalam sebuah pemilu. Kursi, yang ukurannya tak lebih dari 50 kali 50 sentimeter persegi. Penyebutan kursi yang ukurannya tak lebih dari 50 kali 50 sentimeter persegi merupakan salah satu bentuk hiperbol. Hiperbol ini memunculkan kesan cemooh, ejekan. Bahwa kursi yang ukurannya 'hanya' 50 kali 50 sentimeter saja harus diperebutkan dengan berceceran darah.

Data (25) menginformasikan cara-cara negatif yang dilakukan oleh para peserta pemilu untuk mendapatkan kursi yang ' 50 kali 50 sentimeter' tersebut. Cara-cara yang dinyatakan dalam larik-larik ini merupakan kontras dari informasi yang diberikan pada bait kedua [data (22) dan (23)].

Dihasut, berteriak, bersaing, dendam, tinju, naik darah, berkelahi, berbunuhan, tewas, dan dibakar merupakan bentukbentuk negatif yang digunakan untuk menandai ketidakindahan dan ketidakbersihan pemilu yang dilaksanakan pada tahun 1971, 1977, 1982, 1987, 1992, 1997, dan 1999. Tidak cukup sampai di situ. Penutur masih menceritakan perilaku negatif dan kerusakan-kerusakan yang diakibatkan oleh peristiwa-peristiwa pemilu tersebut. Hal itu digambarkan pada larik-larik berikutnya pada data (25). Gambaran perilaku negatif dimulai dengan paradoks satu-satu dengan puluhan apalagi ratusan, sopan-sopan dan beringas, mengamuk, melanggar semua aturan.

Situasi sebagaimana yang digambarkan pada data (25) diakhiri dengan pernyataan //Dalam huru-hara yang malahan mungkin, pesanan//. Larik ini mengimplikasikan bahwa penutur mencurigai bahwa perilaku negatif yang dilakukan rakyat merupakan sebuah peristiwa yang direncanakan. Kata pesanan pada larik tersebut menandai hal itu. Kata pesanan mengimplikasikan adanya orang yang memesan dan orang yang menerima pesanan.

Data (26) yang merupakan tiga larik terakhir dalam puisi ini memberi penegasan tentang perasaan penutur melihat dan mengenang peristiwa-peristiwa pemilu yang ia alami. Pada larik ke-38 penutur menyatakan rasa rindu dan malu. Rindu pada pemilu tahun 1955 dan malu mengenang tujuh pemilu berikutnya yang tidak bisa mengulang keberhasilan pemilu tahun 1955. Larik ke-39 memerikan perasaan rindu tersebut. Puisi ini diakhiri dengan perasaan malu, malu pada diri sendiri. Hal ini mengimplikasikan bahwa penutur merasa ikut memikul tanggung jawab untuk mengubah perilaku bangsa.

(26) Antara rasa rindu dan malu puisi ini kutuliskan

Rindu pada pemilu yang bersih dan indah, pernah kurasakan

Malu pada diri sendiri, tak mampu merubah perilaku bangsaku.

(1.38 s.d. 1.40$)$

Puisi ini disusun dalam tiga bait. Bait pertama terdiri atas 2 larik, bait kedua terdiri atas 21 larik, dan bait ketiga terdiri atas 17 larik. Dua larik pada bait pembuka yang diikuti oleh dua bait perian mengimplikasikan dua situasi yang dialami oleh penutur. Dua situasi tersebut adalah perasaan rindu dan perasaan malu dalam diri penutur. Dua perasaan tersebut dibingkai dalam dua kisah yang ironis. Ada pemilu yang indah dan pemilu yang tidak indah, pemilu yang bersih dan pemilu yang tidak bersih, ada yang simpatik penuh senyuman, ada yang penuh keberingasan. Harapan dan kerinduan terhadap pemilu yang indah dan bersih sangat kuat dalam diri penutur. Kekuatan harapan itu ditunjukkan dengan penggunaan kata-kata bernilai positif yang lebih banyak daripada kata-kata yang bernilai negatif. Demikian pula dalam susunan larik, harapan dan kerinduan dinyatakan dalam 21 larik, sementara situasi 
negatif yang mengakibatkan perasaan malu penutur dinyatakan dalam 14 larik.

\section{SIMPULAN}

Berdasarkan hasil dan pembahasan dalam penelitian ini, dapat disimpulkan hal-hal sebagai berikut sebagai berikut. Ciri tuturan ironi yang ditemukan dalam KIDD adalah kesenjangan semantis dan pemakaian gaya hiperbol. Kesenjangan semantis ditandai oleh kontradiksi leksikal, penjajaran kata yang mengandung komponen makna yang bertentangan, serta pemakaian atau penyisipan kata dengan laras yang kontras. Ciri tuturan yang hiperbol itu ditandai oleh adanya pelanggaran terhadap maksim kuantitas dan maksim kualitas. Kajian atas jenis ironi menunjukkan bahwa ironi yang ditemukan dalam puisi KIDD adalah jenis ironi verbal sebagai bagian struktur pengucapan ironi. Jenis yang juga ditemukan dalam kajian ini adalah jenis ironi

\section{DAFTAR PUSTAKA}

Abrams, M. H. (1981). A Glossary of Literary Terms. Holt, Rinehart \& Wanston.

Aditya, M., Mukti, M. A., \& Lully, S. (2018). Kritik Sosial dalam Kumpulan Puisi Karya Taufiq Ismail. Asas Jurnal Sastra, 7(3), 10--18.

Choon-Soo, K. (1990). Poetry and Irony. The 20th World Congress of Poets.

Febrina, L. (2019). Gaya Kepenyairan Taufik Ismail dalam Sajak Malu (Aku) Jadi Orang Indonesia. Jurnal Sastra Indonesia, 8(3), 197-202.

Fowler, R. (1991). Language in the News: Discourse and Ideology in the Press. In Language in the News: Discourse and Ideology in the Press. Routledge. https://doi.org/10.4324/978131500205 7

Giora, R. (2001). Irony and its discontent. In situasi. Penggunaan bentuk-bentuk ironi tersebut mempunyai dua fungsi, yakni untuk menciptakan metafora dan untuk menegaskan nada menyindir atau mencemooh, yang kadang-kadang sampai pada taraf sarkasme. Paradoks-paradoks yang digunakan memunculkan suasana ironis. Sementara, pemakaian hiperbol mempertegas metafora, dan menghidupkan imaji visual secara lebih kuat. Pemakaian hiperbol yang menimbulkan efek sindiran atau mencemooh lebih menonjolkan ciri ironinya.

Perlu ditegaskan bahwa kajian ini merupakan kajian yang bersifat penjajakan atas salah satu kemungkinan tekstual yang terkandung dalam puisi KIDD. Menjadikan puisi sebagai objek kajian pragmatik juga merupakan hal yang baru, sehingga hasilnya amat mungkin masih jauh dari yang diharapkan. Untuk itu, rasanya perlu untuk senantiasa terus mengembangkan pendekatan ini pada penelitian-penelitian selanjutnya.

The Psychology and Sociology of Literature, In Honor of Elrud Ibsch (pp. 165-184). John Benjamins Publishing Company. https://doi.org/10.1075/upal.35.11gio

Giora, R., \& Fein, O. (1999). Irony : Context and Salience. Metaphor and Symbol, 14(4), 241-257.

Grice, H. P. (1976). Logic and Conversation. In Syntax and Semantics 3: Speech Arts (pp. 41--58). University College London. https://doi.org/10.2307/324613

Hamzah, M. (2010). Melacak Jejak Pemikiran Taufiq Ismail Ihwal Pendidikan Lewat Puisi-Puisinya. Deiksis, 2(3), 178-196.

Husen, I. S. (1990). Ironi dalam Tiga Dongeng Voltaire: Zadig, Candide, dan L'Ingenu. Universitas Indonesia. 
Iswatiningsih, D. (2005). Telaah Semiotika Ragam Bahasa Sastra Taufiq Ismail dalam Kumpulan Puisi "Malu (Aku) Jadi Orang Indonesia." Humanity, 1(1), 17--22.

Kleden, I. (2004). Sastra Indonesia dalam Enam Pertanyaan; Esai-Esai Sastra dan Budaya. Freedom Institute.

Kusumawati, A. A. (2013). Pendidikan Karakter Bangsa dalam Puisi "Malu (Aku) Jadi Orang Indonesia" Karya Taufiq Ismail. Adabiyyat, XII(2), 332-360.

Leech, G. (1983). Principles of Pragmatics. Longman.

Martalena. (2016). Kajian Historis Kumpulan Puisi Tirani dan Benteng karya Taufiq Ismail. Diksa, 2(1), 33-42.

https://doi.org/10.1016/j.cya.2015.11.0 11

Penny, W. K. (2011). A tragic harp: Ritual, irony and myth in the war poetry of Wilfred Owen. Language and Literature: International Journal of Stylistics, 20(2).

Salikha, T. T. (2017). Analisis Strategi Off Record Ironi dalam Tuturan Merendahkan Orang Lain pada Drama Gakkou No Kaidan. Japanology, 5(1), 79-89.

Santosa, P. (2002). Kabar yang Bertolak dari Realitas: Politik dan Gerakan
Mahasiswa dalam Sajak-sajak Taufik Ismail. Konferensi Internasional HISKI XIII.

Sayuti, S. A. (2005). Taufik Ismail: Karya dan Dunianya. Hanindita.

Searle, J. R. (1979). Expression and Meaning. Cambridge University Press.

Septia, E., Marni, S., \& Armet. (2019). Representasi Nilai Religi dan Kepengarangan Puisi-Puisi Karya Taufik Ismail. Jurnal POETIKA, 7(1), $32-50$.

https://doi.org/10.22146/poetika.43493

Shirazy, H. E. (2014). Berdakwah dengan Puisi (Kajian Intertekstual Puisi-Puisi Religius Taufiq Ismail). At-Tabsir Jurnal Komunikasi Penyiaran Islam, 2(1), 35-56. http://journal.stainkudus.ac.id/index.ph p/komunikasi/article/view/462

Sudardi. (2005). Kritik Sosial Ala Taufik Ismail. Balai Bahasa DI Yogyakarta.

Susilo, A., Pratiwi, Y., \& Sunoto. (2018). Relevansi Nilai Sosial dalam Antologi Puisi Malu Aku Jadi Orang Indonesia Karya Taufik Ismail dengan Muatan Isi Kurikulum 2013. Jurnal Pendidikan: Teori, Penelitian, Dan Pengembangan, 3(1), 75-81.

Zaidan, A. R. (1992). Ironi dalam Sajak Goenawan Muhamad. Universitas Indonesia. 